\title{
ANALYSIS OF FOOD TOLERANCE IN PATIENTS SUBMITTED TO BARIATRIC SURGERY USING THE QUESTIONNAIRE QUALITY OF ALIMENTATION
}

Análise da tolerância alimentar em pacientes submetidos à cirurgia bariátrica através do questionário Quality of Alimentation

Matheo Augusto Morandi STUMPF, Marcos Ricardo da Silva RODRIGUES,

Ana Claudia Garabeli Cavalli KLUTHCOVSKY, Fabiana TRAVALINI, Fábio Quirillo MILLÉO

From the Departamento de Medicina da Universidade Estadual de Ponta Grossa (Department of Medicine, State University of Ponta Grossa), Ponta Grossa, PR, Brazil

HEADINGS - Bariatric surgery. Alimentation. Questionnaires.
ABSTRACT - Background: Due to the increased prevalence of obesity in many countries, the number of bariatric surgeries is increasing. They are considered the most effective treatment for obesity. In the postoperative there may be difficulties with the quality of alimentation, tolerance to various types of food, as well as vomiting and regurgitation. Few surveys are available to assess these difficulties in the postoperative. Aim: To perform a systematic literature review about food tolerance in patients undergoing bariatric surgery using the questionnaire "Quality of Alimentation", and compare the results between different techniques. Method: A descriptive-exploratory study where the portals Medline and Scielo were used. The following headings were used in english, spanish and portuguese: quality of alimentation, bariatric surgery and food tolerance. A total of 88 references were found, 14 used the questionnaire "Quality of Alimentation" and were selected. Results: In total, 2745 patients were interviewed of which 371 underwent to gastric banding, 1006 to sleeve gastrectomy, 1113 to Roux-en-Y gastric bypass, 14 to biliopancreatic diversion associated with duodenal switch, 83 were non-operated obese, and 158 non-obese patients. The questionnaire showed good acceptability. The biliopancreatic diversion with duodenal switch had the best food tolerance in the postoperative when compared to other techniques, but it was evaluated in a single article with a small sample. The longer the time after the operation, the better is the food tolerance. Comparing the sleeve gastrectomy and the Rouxen-Y gastric bypass, there are still controversial results in the literature. The gastric banding had the worst score of food tolerance among all the techniques evaluated. Conclusion: The questionnaire is easy and fast to assess the food tolerance in patients after bariatric surgery. Biliopancreatic diversion with duodenal switch had the best food tolerance in the postoperative when compared to sleeve gastrectomy and the Roux-en-Y gastric bypass. Gastric banding still remains in controversy, due it presented the worst score.

\author{
Correspondence: \\ Matheo Augusto Morandi Stumpf \\ E-mail: matheoaugusto@hotmail.com \\ Financial source: none \\ Conflicts of interest: none
}

Received for publication: 20/01/2015 Accepted for publication: 23/04/2015
DESCRTIORES: Cirurgia bariátrica. Alimentação. Questionários
RESUMO - Introdução: Devido ao aumento da prevalência da obesidade em diversos países, o número de operações bariátricas está aumentando. Elas são consideradas o tratamento de maior eficácia da obesidade. No pós-operatório podem ocorrer dificuldades com relação à qualidade da alimentação, tolerância para vários tipos de alimentos, além de vômito e regurgitação. Poucos questionários estão disponíveis para avaliar essas dificuldades no pós-operatório. Objetivo: Realizar revisão sistemática da literatura sobre a tolerância alimentar em pacientes submetidos à cirurgia bariátrica utilizando o questionário "Quality of Alimentation" e comparar os resultados entre as diferentes técnicas. Método: Estudo descritivo-exploratório onde foram pesquisados os portais de periódicos Medline e Scielo. Utilizaram-se os descritores "quality of alimentation, bariatric surgery e food tolerance", em inglês, português e espanhol. Foram encontradas 88 referências, sendo 14 selecionadas por utilizarem o questionário "Quality of Alimentation". Resultados: Ao total, 2745 pacientes foram entrevistados sendo que 371 foram submetidos à bandagem gástrica, 1006 à gastrectomia vertical, 1113 ao bypass gástrico em Y-de-Roux, 14 à derivação biliopancreática associada ao duodenal switch, 83 eram obesos não operados, e 158 pacientes não obesos. O questionário teve boa aceitação. A derivação biliopancreática com duodenal switch apresentou a melhor tolerância alimentar no pós-operatório quando comparada às demais técnicas, mas foi avaliada em um único artigo e com pequena amostra. Quanto maior o tempo de pós-operatório, melhor foi a tolerância alimentar. Comparando a gastrectomia vertical e o bypass gástrico em Y-de-Roux, ainda há resultados controversos na literatura. A banda gástrica apresentou o pior escore de tolerância alimentar dentre todas as técnicas avaliadas. Conclusão: O questionário é de fácil e rápida aplicação para avaliar a tolerância alimentar em pacientes submetidos à cirurgia bariátrica. A derivação biliopancreática com duodenal switch teve a melhor tolerância alimentar no pós-operatório quando comparada à gastrectomia vertical e ao bypass gástrico em Y-de-Roux. Quanto à banda gástrica ainda existe controvérsia quanto ao seu uso, devido à apresentação de piores resultados. 
INTRODUCTION

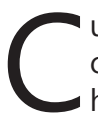
urrently obesity is highly prevalent in several countries. Brazil, in 2012, was estimated to have $17.2 \%$ of obese adults ${ }^{12}$. As the worldwide prevalence, the World Health Organization estimates that in 2015 there are approximately 2300 million adults overweight and over 700 million obese ${ }^{21}$.

Among the possible treatments is the pharmacological approach. The most commonly used agents are: $\beta$-fenetilaminic derivatives, tricyclic, fenilpropanolamic, oxitrifluorfenil phenylpropanolamine, naftilaminic and derived from lipstatine ${ }^{10}$. The major problem of these treatments are the possible side effects and do not result in major weight loss. Currently it is believed that one of the most effective treatments to combat obesity is the bariatric surgery. However, the operation is indicated only for patients with a body mass index (BMI) above $40 \mathrm{~kg} / \mathrm{m}^{2}$ or a BMI between 35 and $39.9 \mathrm{~kg} / \mathrm{m}^{2}$ with associated comorbidities. The clinical treatment failure for more than two years is also necessary for indication ${ }^{22}$

Traditionally, postoperative results in bariatric surgery are valued by BAROS (Bariatric Analysis and Reporting Outcome System). Oria and Moorhead ${ }^{14}$ proposed this questionnaire, where the score is based on the loss of excess weight, improvement in comorbidities and quality of life, and post-surgical complications. Depending on the score is defined if the patient has succeeded or failed operation. However, does not evaluate the food tolerance, which is an important factor in postoperative the different techniques used $^{13}$. Until now, purely restrictive (such as laparoscopic gastric band and sleeve gastrectomy) seem to progress with higher food intolerance when compared to procedures such as malabsortive biliopancreatic diversion associated with duodenal switch or mixed techniques, such as Roux-en-Y gastric bypass (RYGB) ${ }^{18}$

Food intolerance after restrictive techniques tends to improve over time. However, if intolerance persists, the patient may experience severe nutritional deficiencies and commit to weight loss. It must remember that in the presence of behavioral disorders (anxiety and binge eating, so frequent in obese $\left.{ }^{9,11}\right)$, it is necessary interdisciplinary assistance that can better feed adaptation in postoperative ${ }^{4}$.

To specifically assess the food tolerance Suter et al. ${ }^{20}$ proposed a specific questionnaire called "Quality of Alimentation." It consists of four parts: 1 ) overview of patients satisfaction about their food quality; 2) the time between meals and food intake between them; 3) evaluation of the tolerance of eight different types of food; and 4) evaluating the frequency of vomiting or regurgitation. Score is obtained by evaluation of parts 1, 3 and 4 of the questionnaire. Part 1 refers to the general satisfaction as to how one can eat, and presents answers ranging from "excellent" to "very bad". In Part 3 , the question refers to the ability to be able to eat certain types of food without difficulty, with some difficulty or not able to eat. In part 4, the question refers to the frequency of vomiting/regurgitation, with scores ranging from 0 to 6 . Part 2 does not enter the score and have questions relating to the main food of the day, how many meals are made daily and the patient is fed between them. The score can range from 1 to 27,27 being the highest score, referring to the excellent food tolerance.

For validation, questionnaire was administered to 300 patients who underwent gastric banding (BG) and 600 who underwent RYGB. It was also applied in a group of 75 nonobese patients for validation in the normal population, and a group of 55 morbidly obese patients not operated. The authors concluded that the questionnaire was simple to be answered (taking less than two minutes), easy reproducibility and allowing easy comparison between the individuals ${ }^{20}$.
This study was conducted due to the scarcity of publications on the subject of food tolerance in post-bariatric surgery and the importance of better understanding how the surgical techniques differ as to this issue.

The objective therefore was to conduct a systematic review of the literature on studies that used the questionnaire "Quality of Alimentation" to assess food tolerance in patients undergoing bariatric surgery and compare results in different surgical techniques.

\section{METHOD}

This is a systematic review using the periodic portals Medical Literature Analysis and Retrieval System Online (Medline) and Scientific Electronic Library Online (SciELO).

In June 2015, it was accessed the portals using descriptors in English, in the following combinations: "Quality of alimentation, Food tolerance and bariatric surgery", "Food tolerance and Suter", "Food tolerance and bariatric surgery". Also references were searched using the key-words in Portuguese and Spanish, in the same combinations. Were sought only studies published since 2007, the year of publication of the article concerning the questionnaire "Quality of Alimentation." The search resulted in 90 references from Medline and four in Scielo. After exclusion of six repetitions, was proceeded reading the abstracts of the remaining references and, after excluding those not using the proposed questionnaire, were obtained 14 articles, 13 of Medline and one in Scielo. Thus, there was a complete reading of 14 studies, which formed the basis of this paper.

The 14 articles were classified according to the following variables: authors, year of publication, where the study was conducted, sample characteristics, type of study, research objectives, data collection method, and key findings.

\section{RESULTS}

Firstly was sought the name of the first author, year of publication and where the survey was conducted, appearing on the first page of articles. Then, the characteristics of the sample, which the intervention used, type of research (prospective or retrospective), the objectives as described by the authors, the details of the procedures for data collection and the main conclusions. The details of the characteristics of the analyzed articles are shown in Table 1.

Of the 14 articles, 12 were published in English and two in Spanish. In addition, 10 articles were prospective and four retrospective. As for sampling, the total of 2745 patients were interviewed between 14 selected articles. Of these, 371 were submitted to BG, 1006 the vertical gastrectomy (GV), 1113 to RYGB, 14 to biliopancreatic diversion associated with duodenal switch, 83 were not operated or obese before surgery, and 158 were non-obese patients. Table 2 shows this distribution.

TABLE 2 - Distribution of the initial sample of research subjects with and without operation, which evaluated the food tolerance by the questionnaire "Quality of Alimentation"

\begin{tabular}{|c|c|c|c|c|}
\hline \multicolumn{2}{|c|}{ Participants } & Surgical technique & $n$ & $(\%)$ \\
\hline \multirow{4}{*}{\multicolumn{2}{|c|}{$\begin{array}{l}\text { With bariatric } \\
\text { surgery }\end{array}$}} & BG & 371 & 13,6 \\
\hline & & GV & 1006 & 36,6 \\
\hline & & BGYR & 1113 & 40,5 \\
\hline & & $\begin{array}{l}\text { Biliopancreatic diversion } \\
\text { associated with duodenal switch }\end{array}$ & 14 & 0,5 \\
\hline \multirow{2}{*}{$\begin{array}{l}\text { Without } \\
\text { operation }\end{array}$} & Obese & - & 83 & 3 \\
\hline & Non-obeso & - & 158 & 5,8 \\
\hline Total & & & 2745 & 100 \\
\hline
\end{tabular}

$B G=$ gastric band; $G V=$ sleeve gastrectomy; $B G Y R=$ Roux-en $-Y$ gastric bypass 
TABLE 1 - Distribution of published articles that used the questionnaire "Quality of Alimentation" and their characteristics

\begin{tabular}{|c|c|c|c|c|c|}
\hline $\begin{array}{l}\text { Authors, } \\
\text { publication year } \\
\text { and place where } \\
\text { it was held }\end{array}$ & Sample & Study type & Objectives & Collect data & Conclusion \\
\hline $\begin{array}{l}\text { Suter et al. } \\
2007, \\
\text { Switzerland }\end{array}$ & $\begin{array}{l}300 \text { patients after BG, } 600 \\
\text { after RYGB, } 75 \text { non-obese } \\
\text { and } 55 \text { non-operated obese }\end{array}$ & Prospective & $\begin{array}{l}\text { Develop a } \\
\text { questionnaire to assess } \\
\text { food tolerance in the } \\
\text { postoperative follow-up }\end{array}$ & $\begin{array}{l}\text { Quarterly during the } 1^{\text {st }} \\
\text { year after surgery, every } \\
\text { two years from } 2 \text { to } 5 \text { years } \\
\text { after surgery and annually } \\
\text { thereafter }\end{array}$ & $\begin{array}{l}\text { Patients after RYGB had better food } \\
\text { tolerance over time compared to } \\
\text { BG; the questionnaire is reliable, easy } \\
\text { to use and comfortable to the patient }\end{array}$ \\
\hline $\begin{array}{l}\text { Schweiger et al., } \\
\text { 2010, Israel }\end{array}$ & $\begin{array}{c}218 \text { patients (99 after RYGB, } \\
\text { laparoscopic adjustable BG } \\
49 \text { after, } 56 \text { after GV and } \\
14 \text { after biliopancreatic } \\
\text { diversion with duodenal } \\
\text { switch) }\end{array}$ & Prospective & $\begin{array}{l}\text { Evaluate food } \\
\text { intolerance and food } \\
\text { quality compared to } \\
\text { surgical technique and } \\
\text { postoperative time }\end{array}$ & $\begin{array}{c}\text { Patients divided into } \\
3 \text { groups according to } \\
\text { postoperative: } 3-6 \text { months, } \\
6-12 \text { months and longer than } \\
12 \text { months; questionnaire } \\
\text { administered once in each } \\
\text { group }\end{array}$ & $\begin{array}{c}\text { Patients after laparoscopic adjustable } \\
\text { BG had lower quality on food } \\
\text { compared to other techniques } \\
\text { evaluated by the study }\end{array}$ \\
\hline $\begin{array}{l}\text { D'Hont et al., } \\
\text { 2011, Belgium }\end{array}$ & $\begin{array}{c}83 \text { patients after } \\
\text { laparoscopic GV and } 83 \\
\text { non-obese }\end{array}$ & Retrospective & $\begin{array}{l}\text { Compare the } \\
\text { group undergoing } \\
\text { laparoscopic GV with } \\
\text { the non-obese }\end{array}$ & $\begin{array}{l}\text { Postoperatively GV } \\
\text { laparoscopic and is not } \\
\text { specified at what time }\end{array}$ & $\begin{array}{l}\text { The tolerance was significantly higher } \\
\text { in non-obese patients }\end{array}$ \\
\hline $\begin{array}{l}\text { Keren et al., } \\
\text { 2011, Israel }\end{array}$ & $\begin{array}{l}119 \text { patients after } \\
\text { laparoscopic GV, } 83 \\
\text { regularly followed } \\
\text { postoperatively and } 36 \\
\text { irregularly }\end{array}$ & Retrospective & $\begin{array}{l}\text { Compare the two post- } \\
\text { surgical groups GV } \\
\text { laparoscopic }\end{array}$ & $\begin{array}{l}\text { In both groups to complete } \\
30 \text { months of postoperative } \\
\text { follow-up }\end{array}$ & $\begin{array}{l}\text { The group that showed regular } \\
\text { consultations at the clinic showed } \\
\text { better food tolerance }\end{array}$ \\
\hline $\begin{array}{l}\text { Romy et } \\
\text { al., 2012, } \\
\text { Switzerland }\end{array}$ & $\begin{array}{l}442 \text { patients ( } 221 \text { and } 221 \\
\text { after GV and RYGB) }\end{array}$ & Prospective & $\begin{array}{l}\text { Compare the two } \\
\text { surgical techniques }\end{array}$ & $\begin{array}{l}\text { At } 1,2,3,4 \text { and } 5 \text { years } \\
\text { postoperatively }\end{array}$ & $\begin{array}{l}\text { The food had better tolerance and } \\
\text { remained unchanged after RYGB }\end{array}$ \\
\hline $\begin{array}{l}\text { Ramon et al., } \\
\text { 2011, Spain }\end{array}$ & $\begin{array}{l}105 \text { patients, } 64 \text { underwent } \\
\text { GV and } 41 \text { gastric bypass }\end{array}$ & Prospective & $\begin{array}{l}\text { Assess the impact of GV } \\
\text { and gastric bypass in } \\
\text { food quality }\end{array}$ & $\begin{array}{l}\text { Preoperatively and } 3, \\
6,12 \text { and } 24 \text { months } \\
\text { postoperatively }\end{array}$ & $\begin{array}{l}\text { The food quality has worsened in the } \\
\text { first months after surgery, improving } \\
\text { gradually. There were no differences } \\
\text { between the techniques evaluated }\end{array}$ \\
\hline $\begin{array}{l}\text { Overs et al., } \\
\text { 2012, Australia }\end{array}$ & $\begin{array}{c}129 \text { patients ( } 13 \text { after } \\
\text { adjustable BG, } 41 \text { after } \\
\text { RYGB, after GV } 62 \text { and } 14 \\
\text { pre-surgical obese patients) }\end{array}$ & Prospective & $\begin{array}{l}\text { Investigate and } \\
\text { compare food tolerance } \\
\text { after adjustable BG, } \\
\text { RYGB and GV }\end{array}$ & $\begin{array}{c}\text { Between } 2-4 \text { years of } \\
\text { postoperative }\end{array}$ & $\begin{array}{l}\text { The control group (non- } \\
\text { operated obese) had better food } \\
\text { tolerance. Adjustable patients after } \\
\text { BG had lower food tolerance than the } \\
\text { other techniques evaluated }\end{array}$ \\
\hline $\begin{array}{l}\text { Godoy et al., } \\
\text { 2012, Brazil }\end{array}$ & 47 patients after RYGB & Prospective & $\begin{array}{l}\text { Investigate the level } \\
\text { of food tolerance after } \\
\text { RYGB }\end{array}$ & $\begin{array}{l}\text { Average } 2 \text { years } \\
\text { postoperatively }\end{array}$ & $\begin{array}{l}\text { Patients with lower socioeconomic } \\
\text { status have shown significant worst } \\
\text { food tolerance }\end{array}$ \\
\hline $\begin{array}{l}\text { Sioka et al. } \\
2013 \text { Greece }\end{array}$ & 110 patients after GV & Prospective & $\begin{array}{l}\text { To evaluate the } \\
\text { dietary profile after } \\
\text { laparoscopic GV }\end{array}$ & $\begin{array}{c}\text { Group } 1 \text { (postoperative } \\
<3 \text { months), group } 2 \text { (3-6 } \\
\text { months), group } 3 \text { (6-12 } \\
\text { months), Group } 4 \text { (1-2 years), } \\
\text { Group } 5 \text { ( } 2-3 \text { years) and } 6 \\
\text { group ( }>3 \text { years) }\end{array}$ & $\begin{array}{l}\text { Improved food tolerance after the } \\
\text { first year of laparoscopic GV }\end{array}$ \\
\hline $\begin{array}{l}\text { Keren et al., } \\
2014 \text { Israel }\end{array}$ & $\begin{array}{l}114 \text { patients after } \\
\text { laparoscopic GV }\end{array}$ & Retrospective & $\begin{array}{l}\text { Evaluate the long-term } \\
\text { food tolerance after } \\
\text { laparoscopic GV }\end{array}$ & $\begin{array}{l}\text { At } 30 \text { and } 60 \text { months } \\
\text { postoperatively }\end{array}$ & $\begin{array}{l}\text { Food tolerance at } 30 \text { months was } \\
\text { better than at } 60 \text { months, with no } \\
\text { significant difference }\end{array}$ \\
\hline $\begin{array}{l}\text { Kafri et al. } \\
2013 \text { Israel }\end{array}$ & $\begin{array}{c}37 \text { patients ( } 12 \text { GV revised } \\
\text { after laparoscopic and } 25 \\
\text { after primary laparoscopic } \\
\text { GV) }\end{array}$ & Prospective & $\begin{array}{l}\text { Investigate food } \\
\text { tolerance between the } \\
\text { two groups }\end{array}$ & $\begin{array}{l}\text { Average } 18 \text { months } \\
\text { postoperatively in both } \\
\text { groups }\end{array}$ & $\begin{array}{l}\text { Food tolerance was lower in } \\
\text { laparoscopic GV revised }\end{array}$ \\
\hline $\begin{array}{l}\text { Freeman et al., } \\
\text { 2014, Australia }\end{array}$ & $\begin{array}{c}130 \text { patients ( } 14 \text { pre-surgical } \\
\text { obese controls, adjustable } \\
\text { BG } 13 \text { after, } 62 \text { after GV and } \\
41 \text { after RYGB) }\end{array}$ & Prospective & $\begin{array}{c}\text { Evaluate food tolerance } \\
\text { between adjustable BG, } \\
\text { GV and RYGB }\end{array}$ & $\begin{array}{c}\text { Between } 2-4 \text { years of post- } \\
\text { operative }\end{array}$ & $\begin{array}{l}\text { Positive association between food } \\
\text { intolerance and diet quality, low food } \\
\text { tolerance considered as post-surgical } \\
\text { complication after adjustable BG } \\
\text { compared to GV and RYGB }\end{array}$ \\
\hline $\begin{array}{l}\text { Kafri et al., 2011, } \\
\text { Israel }\end{array}$ & $\begin{array}{l}60 \text { patients after } \\
\text { laparoscopic GV }\end{array}$ & Retrospective & $\begin{array}{l}\text { Evaluate food tolerance } \\
\text { in two postoperative } \\
\text { moments }\end{array}$ & $\begin{array}{c}\text { Group } 1 \text { over a year of } \\
\text { monitoring and Group } 2 \text { less } \\
\text { than one year }\end{array}$ & $\begin{array}{l}\text { Significant improvement of food } \\
\text { tolerance over time }\end{array}$ \\
\hline $\begin{array}{l}\text { Acosta et al., } \\
\text { 2010, Venezuela }\end{array}$ & $\begin{array}{c}41 \text { patients ( } 23 \text { after RYGB } \\
\text { and } 18 \text { after laparoscopic } \\
\text { GV) }\end{array}$ & Prospective & $\begin{array}{l}\text { To evaluate changes } \\
\text { in quality of life and } \\
\text { tolerance to food after } \\
\text { bariatric surgery }\end{array}$ & $\begin{array}{l}\text { Preoperatively and } 3.6 \text { and } 9 \\
\text { months postoperatively }\end{array}$ & $\begin{array}{l}\text { Worsening of tolerance at } 3 \text { months } \\
\text { postoperatively, improving over time }\end{array}$ \\
\hline
\end{tabular}

$B G=$ gastric band; $B G Y R=$ Roux-em $-Y$ gastric bypass; $G V=$ sleeve gastrectomy

\section{DISCUSSION}

The questionnaire "Quality of Alimentation" was validated by Suter et al..$^{20}$ in 2007 and is used in 300 patients undergoing BG and 600 RYGB, as well as validation in control groups. The authors observed that after BG, food tolerance was considerably reduced compared to the normal population. The RYGB, in turn, decreased the tolerance in the first year after surgery, especially in the first half due to postoperative edema, but returned to normal thereafter. When comparing the techniques, it was noted (except in the first quarter) that food tolerance in RYGB was significantly much better than in BG. This pioneering study has shown that the quality of food has decreased in both techniques, but improved over time and is affected by the type of chosen procedure.

Studies comparing BG with any other surgical technique came to the conclusion that it is the procedure with poor food tolerance in postoperative ${ }^{3,15,18,20}$. Because it is purely restrictive technique, this result was expected. Several authors have formulated hypotheses to explain the poor performance 
of the band. It could be adjusted, worsening the level of food tolerance. Possible inflammation due to foreign material and complications such as erosion or collapse of the bandage could also explain these results $15,18,20$

It is reported that up to one third of cases of removal of the band is allocated to persistent food intolerance, even after its total emptying ${ }^{15}$. In Brazil, this is one of the least used techniques for weight loss by surgeons.

A study ${ }^{3}$ correlated food tolerance and quality of the diet. In BG, whose procedure had the worst tolerance, it was also demonstrated poorer diet quality. Associated with this, the patients ended up having less weight loss when compared to other techniques evaluated (GV and RYGB). This is due to the low feeding tolerance, which "force" patients to ingest high-calorie semi-liquid foods such as, for example, condensed milk, ice cream and chocolate.

Comparisons between RYGB and GV, mixed and restrictive techniques, respectively, have shown controversial results in literature ${ }^{1,3,15-18}$. Some reports improved food tolerance in mixed technique, as expected ${ }^{17,18}$. Others showed that GV showed better food tolerance in postoperative ${ }^{1,3,15}$. Yet another study found no difference between any of these techniques ${ }^{16}$. These controversies in the literature can be justified by several variables that could have changed the results, such as longer follow-up with a greater chance of gastrointestinal adaptation and hence greater tolerance; inclusion of a control group for comparison with the patients who underwent the operation; significant sample size for correct statistical evaluation and subjective score of the questionnaire (part 1 ) with high results due to satisfaction with weight loss and not the food itself. In view of these variables it's hard to really establish which of these two techniques results in better food tolerance; more studies in this area are needed.

Food tolerance after using the biliopancreatic diversion technique associated with duodenal switch was the one that had better food tolerance when compared to BG, GV and RYGB. This result supports the hypothesis that disabsorptive or mixed procedures end up having better alimentary tolerance ${ }^{18}$.

Studies ${ }^{6-7,19}$ specifically evaluated whether the time of postoperative follow-up on the GV influenced food tolerance. The literature has demonstrated that with the passage of time tends to improve ${ }^{6,19}$ feeding tolerance, not only in the GV technique, but also in other ${ }^{18,20}$. Among all the articles, one of them did not observe significant differences in food tolerance among patients undergoing laparoscopic GV, at 30 and 60 months after ${ }^{7}$. Perhaps this finding can be explained by the small weight loss the study population, since 82 of the 114 patients did not reach $50 \%$ loss of excess weight at 60 months postoperatively. This could influence the subjective score of the questionnaire, as previously mentioned.

In a study of specific assessment of food tolerance in non-obese patients and in patients undergoing GV, it was observed that food tolerance was better in the pre-operative ${ }^{2}$, as well as everyone else that compare to a control group non-operated ${ }^{3,15}, 20$, realizing that food tolerance is better preoperatively. However, in RYGB late postoperative is possible to have the same food tolerance than controls ${ }^{20}$, lacking long-term studies to assess food tolerance before and after surgery.

It is of great importance to active participation by patients postoperatively. It has been shown that after 30 months of follow-up, patients who underwent laparoscopic GV participating actively, went regularly to consultation and had access to multi-professional team, had better food tolerance than the group that did not participate ${ }^{8}$. A study in Brazil showed the importance of the multidisciplinary team; the Brazilian Society of Bariatric and Metabolic Surgery recommends this staff to care patients with obesity. With it, it is easier to perform specific optimization for food tolerance, with better degree of adaptation after surgery with the recommendations and correct monitoring ${ }^{4}$. This same paper also demonstrated that low educational level is associated with low food tolerance after surgery, most likely due to poor adherence in follow-up visits.

Comparing the laparoscopic GV primary done and GV as revision procedure made after failure of adjustable $B G$, was found something interesting. Food tolerance was significantly lower in the second group, as well as higher frequency of vomiting. With these results it is necessary to develop specific pre- and post-surgical treatment to promote better behavioral results for the increasing number of patients undergoing to repeat bariatric surgery ${ }^{5}$.

The questionnaire "Quality of Alimentation" is simple and fast to be filled, but some conditions on its implementation are needed. The part 1 has influence on the comparison of techniques RYGB and GV, as the subjective component interfere in the final score. Part 2 of the questionnaire does not enter in final score and in most of the analyzed studies, was not used. Another factor was related to the questionnaire name. Articles in English, for the most part, use the term FTS (Food Tolerance Score) to refer to the questionnaire. As for the articles in Spanish use the term Calidad de la Alimentación. Ideally the use of standardized questionnaire original name (Quality of Alimentation) with their translations should be recommended. This would facilitate the search for publications about its use and avoid confusion in interpretation.

However, more research needs to be carried out comparing the usual surgical techniques in long-term follow-up.

\section{CONCLUSION}

The questionnaire "Quality of Alimentation" is fast and easy way to evaluate food tolerance in patients subjected to various techniques of bariatric surgery. The biliopancreatic diversion with duodenal switch has the best food tolerance postoperatively compared to vertical gastrectomy and Roux-en- $Y$ gastric bypass. As for gastric banding, there is still controversy with its use, since it showed the worst results.

\section{REFERENCES}

1. Acosta V, Medina R, Leyba JL, Navarrete S. Calidad de vida em pacientes obesos sometidos a bypass gástrico laparascópico em "Y" de Roux y gastrectomía vertical laparoscópica. Rev. Fac. Med. 2010; 31(1): 29-35.

2. D'Hont M, Vanneste S, Pottel H, Devriendt D, Rooy FV, Vansteenkiste F. Laparoscopic sleeve gastrectomy as a single-stage procedure for the treatment of morbid obesity and the resulting quality of life, resolution of comorbidities, food tolerance, and 6-year weight loss. Surg Endosc 2011; 25:2498-2504.

3. Freeman RA, Overs SE, Zarshenas N, Walton K, Jorgensen JO. Food tolerance and diet quality following adjustable gastric banding, sleeve gastrectomy and Roux-en-Y gastric bypass. Obes Res Clin Pract 2014, 8(2):115-200.

4. Godoy CMA, Caetano AL, Viana KRS, Godoy EP, Barbosa ALC, Ferraz EM. Food Tolerance in Patients Submitted to Gastric Bypass: The Importance of Using an Integrated and Interdisciplinary Approach. Obes Surg 2012; 22:124-130.

5. Kafri N, Valfer R, Nativ O, Shiloni E, Hazzan D. Behavioral Outcomes Following Laparoscopic Sleeve Gastrectomy Performed After Failed Laparoscopic Adjustable Gastric Banding. Obes Surg 2013; 23:346352.

6. Kafri N, Valfer R, Nativ O, Shiloni E, Hazzan D. Health behavior, food tolerance, and satisfaction after laparoscopic sleeve gastrectomy. Surg Obes Relat Dis 2011; 7(1):82-88.

7. Keren D, Matter I, Lavy A. Lifestyle Modification Parallels to Sleeve Success. Obes Surg 2014; 24:735-740. 
8. Keren D, Matter I, Rainis T, lavy A. Getting the Most from the Sleeve: The Importance of Post-Operative Follow-up. Obes Surg 2011; 21:1887-1893.

9. Machado CE, Zilberstein B, Cecconello I, Monteiro M. Compulsão alimentar antes e após a cirurgia bariátrica. $A B C D$, arq. bras. cir. dig. 2008; 21(4):185-191.

10. Mancini MC, Halpern A. Tratamento farmacológico da obesidade. Arq Bras Endocrinol Metabol. 2002; 46(5): 497-513

11. Marchesini SD. Acompanhamento psicológico tardio em pacientes submetidos à cirurgia bariátrica. ABCD, arq. bras. cir. dig. 2010 23(2):108-113.

12. Ministério da Saúde (BR). Vigilância de fatores de risco e proteção para doenças crônicas por inquérito telefônico:Vigitel2012 [Internet]. [Acesso em: 15 de abril de 2015]. Brasília: Ministério da Saúde; 2012. Disponível em: www.saude.gov.br/svs.

13. Moreira MA, Espínola PRMI, Azevedo CW. Food intolerances and associated symptoms in patients undergoing Fobi-Capella technique without gastric ring. $A B C D$, arq. bras. cir. dig. 2015; 28(1):36-39.

14. Oria $\mathrm{HE}$, Moorehead MK. Bariatric analysis and reporting outcome system (BAROS). Obes Surg. 1998; 8(5): 487-499.

15. Overs SE, Freeman RA, Zarshenas N, Walton KL, Jorgensen JO. Food Tolerance and Gastrointestinal Quality of Life Following Three Bariatric Procedures: Adjustable Gastric Banding, Roux-en-Y Gastric Bypass, and Sleeve Gastrectomy. Obes Surg 2012; 22:536-543.
16. Ramón JM, González CG, Dorcaratto D, Goday A, Benaiges D, González S, Pera M, Grande L. Calidad de la ingesta alimentaria tras la cirugía bariátrica: gastrectomía vertical vs bypass gástrico. Cir Esp 2012; 90(2):95-101.

17. Romy S, Donadini A, Giusti V, Suter M. Roux-en-Y Gastric Bypass vs Gastric Banding for Morbid Obesity. Arch Surg 2012; 147(5):460-466.

18. Schweiger C, Weiss R, Keidar A. Effect of Different Bariatric Operations on Food Tolerance and Quality of Eating. Obes Surg 2010; 20:13391399.

19. Sioka E, Tzovaras G, Oikonomou K, Katsogridaki G, Zachari E, Papamargaritis D, Pinaka O, Zacharoulis D. Influence of Eating Profile on the Outcome of Laparoscopic Sleeve Gastrectomy. Obes Surg 2013; 23:501-508.

20. Suter M, Calmes JM, Paroz A, Giusti V. A New Questionnaire for Quick Assessment of Food Tolerance after Bariatric Surgery. Obes Surg 2007; 17:2-8.

21. World Health Organization(WHO). Obesity and overweight [Internet]. [Acesso em: 15 de abril de 2015]. Disponível em: http://www.who. int/mediacentre/factsheets/fs311/en/print.html.

22. Zeve JLM, Novais PO, Júnior NO. Técnicas em cirurgia bariátrica: uma revisão da literatura. Revista Ciência \& Saúde. 2012; 5(2): 132-140. 